\title{
Seismicity and Seismotectonics of the Western Lake Ontario Region
}

\author{
La sismicité et la sismotectonique de la partie ouest du lac \\ Ontario
}

\section{Seismik und Seismotektonik des westlichen Teils der Ontario-See-Region}

\author{
Arsalan A. Mohajer
}

Volume 47, numéro 3, 1993

La néotectonique de la région des Grands Lacs

Neotectonics of the Great Lakes area

URI : https://id.erudit.org/iderudit/032963ar

DOI : https://doi.org/10.7202/032963ar

Aller au sommaire du numéro

\section{Éditeur(s)}

Les Presses de l'Université de Montréal

\section{ISSN}

0705-7199 (imprimé)

1492-143X (numérique)

\section{Découvrir la revue}

Citer cet article

Mohajer, A. A. (1993). Seismicity and Seismotectonics of the Western Lake Ontario Region. Géographie physique et Quaternaire, 47(3), 353-362.

https://doi.org/10.7202/032963ar
Résumé de l'article

Cette région, habituellement perçue comme étant de faible sismicité, est densément peuplée et abrite notamment les réacteurs nucléaires de Pickering et de Darlington. En vue de cela, on doit réévaluer les risques de séismes dans la région. Afin d'améliorer la détermination des sources sismiques et, par là, l'évaluation des risques sismiques, on a recalculé les hypocentres d'une trentaine de séismes locaux. Une nouvelle compilation des données, fondée sur les localisations corrigées ou sur celles comprenant le temps de propagation résiduel le plus court, montre que les microséismes locaux (ML=s3.5) surviennent généralement le long ou à l'intersection d'anomalies gravitaires ou aéromagnétiques prononcées. Une zone sismique appréciable s'étend du nord-est au sud-ouest, entre Toronto et Hamilton, et est bordée par des linéaments magnétiques. Une structure géologique majeure, l'aire limite de la zone métasédimentaire centrale, coïncide avec une forte anomalie aéromagnétique qui s'étend vers le nord-est, dans la zone sismique de l'ouest du Québec. Ce linéament magnétique s'étend aussi vers le sud, à travers le lac Ontario, pour rejoindre la limite magnétique d'Akron (Ohio) qui a été associée à de nombreux séismes connus et à un séisme de $m b=4,9$, en 1986. La plupart des séismes enregistrés par des instruments au cours du XXe s. se sont produits à des profondeurs de 5 à $20 \mathrm{~km}$. Cette observation établit la corrélation entre les séismes locaux et les données géologiques et géophysiques en profondeur, indiquant ainsi une réactivation contemporaine des structures du socle. Cette conclusion implique qu'une évaluation déterministe plus classique des risques sismiques doit être faite afin de tester l'approche probabiliste actuellement entreprise pour évaluer les risques sismiques dans le sud de l'Ontario.
Tous droits réservés @ Les Presses de l'Université de Montréal, 1993
Ce document est protégé par la loi sur le droit d'auteur. L'utilisation des services d'Érudit (y compris la reproduction) est assujettie à sa politique d'utilisation que vous pouvez consulter en ligne.

https://apropos.erudit.org/fr/usagers/politique-dutilisation/ 


\title{
SEISMICITY AND SEISMOTECTONICS OF THE WESTERN LAKE ONTARIO REGION
}

\author{
Arsalan A. MOHAJER*, Environmental Science, Scarborough Campus, University of Toronto, 1265 Military Trail,
} Scarborough, Ontario M1C $1 \mathrm{~A} 4$.

ABSTRACT The western Lake Ontario
region, a traditionally perceived area of low
seismic risk, is densely populated and is
home to, among other critical facilities, the
nuclear reactors of Pickering and Darlington.
These and other characteristics of the region
call for improved estimates of seismic haz-
ard. Due to a lack of understanding of the
causative geological sources and recurrence
characteristics of the reported seismic activ-
ity, there is considerable uncertainty regard-
ing estimated ground motion parameters, a
fundamental component of seismic hazard
assessments. To attempt to improve the def-
inition of the seismic source zones and, con-
sequently, seismic hazard assessments, the
hypocentres of about 30 local earthquakes
were recomputed. A new data compilation,
based on the revised locations or those with
the least travel-time residuals, shows that
local microearthquakes $\left(\mathrm{M}_{\mathrm{L}} \leqslant 3.5\right)$ generally
occur along, or at the intersection of, promi-
nent aeromagnetic or gravity anomalies. A
notable seismicity trend extends in a northeast-southwest direction between Toronto and Hamilton, and is bounded by magnetic lineaments. A major geological structure, the Central Metasedimentary Belt Boundary Zone (CMBBZ), coincides with a strong aeromagnetic anomaly which extends to the northeast into the Western Québec Seismic Zone. This magnetic lineament also extends to the south, across Lake Ontario, to join the Akron (Ohio) magnetic boundary that was associated with several historical earthquakes and with a $m_{b}=4.9$ earthquake in 1986. Most of the seismic events recorded instrumentally in the 20th century have occurred within a depth range of 5 to $20 \mathrm{~km}$. This observation supports the correlation of local earthquakes with deep geophysical and geological features, suggesting contemporary reactivation of basement structures. This may imply that a more conservative deterministic hazard estimate is needed to verify the probabilistic approach currently used to assess seismic hazard in southern Ontario.
RÉSUMÉ La sismicité et la sismotectonique de la partie ouest du lac Ontario. Cette région, habituellement perçue comme étant de faible sismicité, est densément peuplée et abrite notamment les réacteurs nucléaires de Pickering et de Darlington. En vue de cela, on doit réévaluer les risques de séismes dans la région. Afin d'améliorer la détermination des sources sismiques et, par là, l'évaluation des risques sismiques, on a recalculé les hypocentres d'une trentaine de séismes locaux. Une nouvelle compilation des données, fondée sur les localisations corrigées ou sur celles comprenant le temps de propagation résiduel le plus court, montre que les microsèismes locaux $\left(\mathrm{M}_{\mathrm{L}} \leqslant 3.5\right)$ surviennent généralement le long ou à l'intersection d'anomalies gravitaires ou aéromagnétiques prononcées. Une zone sismique appréciable s'étend du nord-est au sudouest, entre Toronto et Hamilton, et est bordée par des linéaments magnétiques. Une structure géologique majeure, l'aire limite de la zone métasédimentaire centrale, coïncide avec une forte anomalie aéromagnétique qui s'étend vers le nord-est, dans la zone sismique de l'ouest du Québec. Ce linéament magnétique s'étend aussi vers le sud, à travers le lac Ontario, pour rejoindre la limite magnétique d'Akron (Ohio) qui a été associée à de nombreux séismes connus et à un séisme de $m_{b}=4,9$, en 1986. La plupart des séismes enregistrés par des instruments au cours du $X X X^{\circ} \mathrm{s}$. se sont produits à des profondeurs de 5 à $20 \mathrm{~km}$. Cette observation ètablit la corrélation entre les séismes locaux et les données géologiques et géophysiques en profondeur, indiquant ainsi une réactivation contemporaine des structures du socle. Cette conclusion implique qu'une évaluation déterministe plus classique des risques sismiques doit être faite afin de tester l'approche probabiliste actuellement entreprise pour évaluer les risques sismiques dans le sud de l'Ontario.

* Also at Seismican Geophysical Ltd., 239 Dunview Avenue, North York, Ontario M2N 4J3 Manucrit révisé accepté le 2 août 1993

ZUSAMMENFASSUNG Seismik und Seismotektonik des westlichen Teils der Ontario-See-Region. Die westliche OntarioSee-Region, die man gewöhnlich für eine Region mit niedrigem seismischem Risiko hält, ist dicht besiedelt und beherbergt unter anderen bedenklichen Einrichtungen die Kernkraftwerke von Pickering und Darlington. Diese sowie andere Charakteristika der Region machen eine Verbesserung der Beurteilung des seismischen Risikos notwendig. Um die Definition seismischer Ursprungszonen und dadurch die Einschätzung des seismischen Risikos zu verbessern, hat man die Hypozentren von etwa 30 lokalen Erdbeben neu berechnet. Eine neue Datenzusammenstellung, gestützt auf korrigierte Lagebestimmungen oder solche mit der geringsten Restverbreitungszeit, zeigt, daß örtliche Mikroerdbeben $\left(M L_{L} \leqslant 3.5\right)$ gewöhnlich entlang oder an der Kreuzung von deutlichen Aeromagnetikoder Gravitations-Anomalien auftreten. Eine beachtliche seismische Zone erstreckt sich von Nordost nach Südwest zwischen Toronto und Hamilton und ist durch magnetische Lineamente begrenzt. Eine bedeutende geologische Struktur, der Grenzbereich des zentralen metasedimentären Gürtels, stimmt mit einer deutlichen aeromagnetischen Anomalie überein, die sich nach Nordosten in die seismische -Zone von West-Québec erstreckt. Dieses magnetische Lineament erstreckt sich auch nach Süden, quer durch den Ontario-See und verbindet sich mit der magnetischen Grenze von Akron(Ohio), welche mit einigen historischen Erdbeben sowie einem $\mathrm{mb}_{b}=4.9$ Erdbeben von 1986 in Verbindung gebracht wurde. Die meisten seismischen Vorkommen, die im 20. Jahrhundert festgestellt wurden, haben in einer Tiefe zwischen 5 bis $20 \mathrm{~km}$ stattgefunden. Diese Feststellung stützt die Korrelationen örtlicher Erdbeben mit tiefgelegenen geophysikalischen und geologischen Charakteristika und weist auf eine zeitgenössische Reaktivierung der Grundstrukturen. Dies könnte zu dem SchlußB führen, daß eine mehr konservative deterministische Risikoeinschätzung notwendig ist, um die gegenwärtig gebrauchte Wahrscheinlichkeitsmethode bei der Einschätzung von seismischen Risiken in SüdOntario zu überprüfen. 


\section{INTRODUCTION}

The western Lake Ontario region, as defined in this study, is bounded by latitudes $43^{\circ}$ and $45^{\circ} \mathrm{N}$ and longitudes $78^{\circ}$ and $80^{\circ} \mathrm{W}$ and covers an area of about $150 \times 220 \mathrm{~km}$. The Canadian portion of this region is generally perceived as one of tectonic stability and low seismic risk (Basham, 1975; Basham et al., 1985) because no large magnitude earthquake has been documented there. The perception of a low risk environment on the Canadian side of Lake Ontario is incompatible with the major-risk designation on the American side (Algermissen et al., 1990). Furthermore, no plausible explanation has been offered for the occurrence of more than 50 earthquakes $(M<5)$, reported in the region during the nineteenth and first half of the twentieth centuries (Fig. 1).

Seismicity in the study area includes the 1929 Attica, New York State, event $\left(m_{b}=5.2\right)$ as well as a series of small magnitude events $(M<3.5)$ near Burlington in the mid-1970's (Wetmiller, 1980). In recent years three small earthquakes of $M_{L}=3.4,3.3,2.2$ occurred beneath the western end of Lake Ontario, one in July 1987 and two in August 1989, in addition to two well recorded $M_{L}=2.5$ event near Hamilton in December 1991 and in April 1993 (Tables I and III). These events, together with recent evidence for unexpected large magnitude intraplate seismicity in eastern Canada (e.g.
Adams and Basham, 1991), have raised concerns regarding the potential of moderate to large magnitude earthquakes to occur in the study area. This is of considerable significance given the presence of several nuclear facilities and the large population there.

Earthquake hazard analysis in Canada relies essentially on recorded earthquake data. Earthquake catalogues, maintained by the Geological Survey of Canada (GSC), provide general information on earthquakes including date of occurrence, location, magnitude, focal depth and travel time residuals (an indication of accuracy of location determinations). The ability to record earthquakes of a given magnitude has varied considerably over time such that it is only within the last 20 years that the existing catalogues can be considered complete to magnitude 4 and above. This has caused a wide range of uncertainties in the estimation of recurrence relationships which are used in assessing earthquake risk.

The limited number of stations in southern Ontario has yielded mislocations of on the order of 40 to $50 \mathrm{~km}$ for some of the older events (Basham et al., 1982; Mohajer, 1987) which is well above the national average of $20 \mathrm{~km}$. Recomputation of earthquake locations has, therefore, been suggested as a possible means of improving the data base to be used for definition of seismic source zones. This may

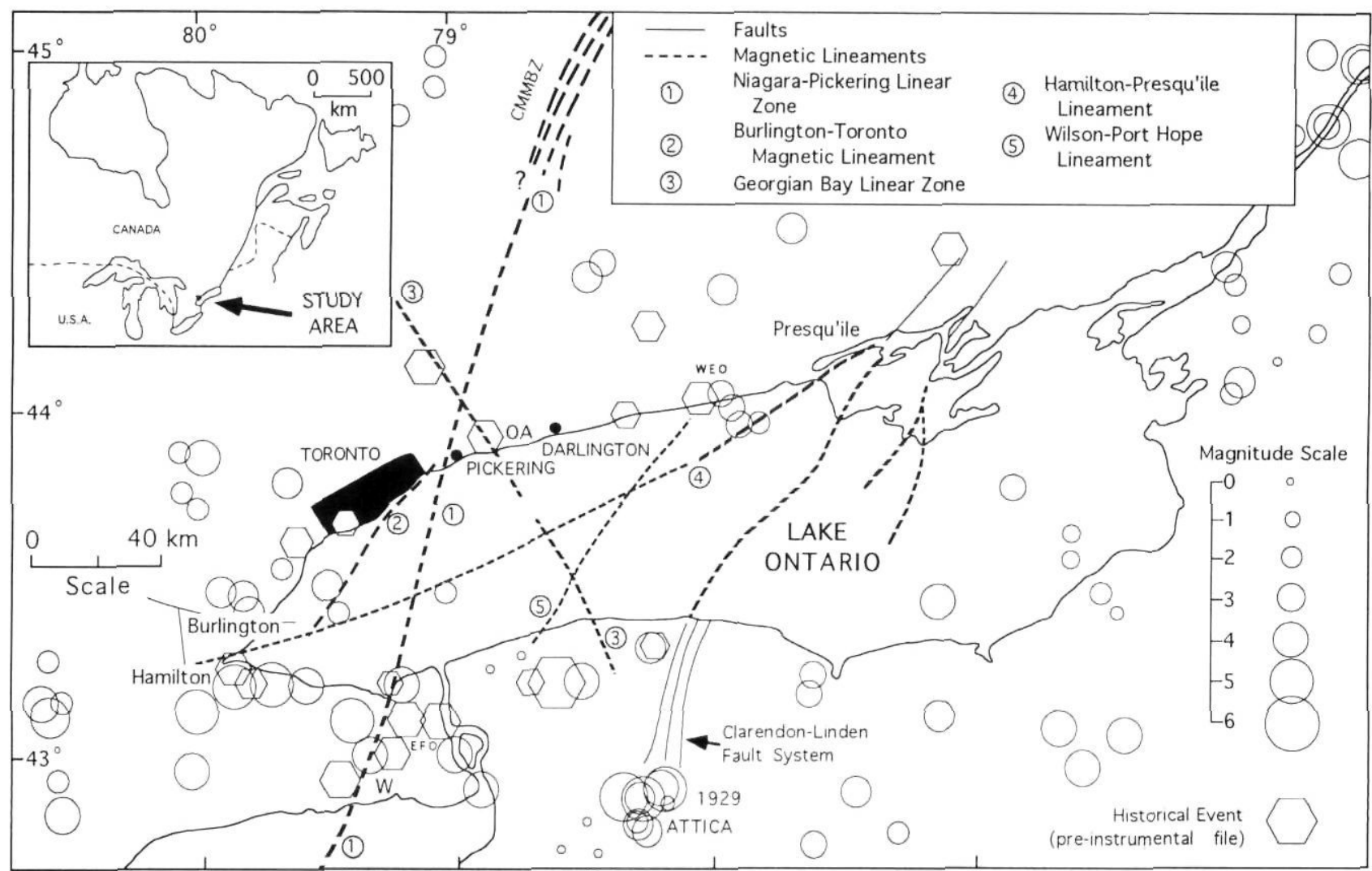

FIGURE 1. Seismicity of the Lake Ontario region, compiled by J.R. Bowlby (pers. comm.), and updated in this study. Additional information from Wallach (1990), Wallach and Mohajer (1990), McFall and Allam (1991), Thurston (1991), Mohajer et al. (1992), and Thomas et al. (1993). WEO (Welcome) and EFO (Effingham) are Geological Survey of Canada seismic stations. $\mathrm{OA}=$ Oshawa and $\mathrm{W}=$ Welland.
Sismicité de la région du lac Ontario, établie par J.R. Bowlby (comm. pers.) et mise à jour. Les données complémentaires proviennent de Wallach (1990), Wallach et Mohajer (1990), McFall et Allam (1991), Thurston (1991), Mohajer et al. (1992), et Thomas et al. (1993). WEO (Welcome) et EFO (Effingham) sont des stations sismiques de la Commission géologique du Canada. $O A=$ Oshawa et $W=$ Welland. 
TABLE ।

Earthquakes possibly associated with the Burlington-Toronto magnetic lineament (BTML), eastern boundary of the Toronto-Hamilton Seismic Zone (THSZ)

\begin{tabular}{lccccr}
\hline Date & $\begin{array}{c}\text { Origin } \\
\text { Time }\end{array}$ & Lat. & Long. & Mag. & $D(\mathrm{~km})$ \\
\hline $1886 / 08 / 19$ & 080000. & 43.60 & 79.60 & 3.0 & $10 \pm 40$ \\
$1894 / 02 / 24$ & 040000. & 43.65 & 79.40 & 2.4 & $4 \pm 40$ \\
$1975 / 06 / 30$ & 152700. & 43.44 & 79.51 & 3.0 & $3 \pm 25$ \\
$1975 / 06 / 30$ & 201523. & 43.36 & 79.75 & 3.0 & $18 \pm 20$ \\
$1987 / 03 / 06$ & 193000. & 43.50 & 79.60 & 2.0 & $7 \pm 15$ \\
$1987 / 03 / 08$ & 240000. & 43.55 & 79.50 & 1.0 & $4 \pm 10$ \\
$1987 / 07 / 23$ & 093200. & 43.49 & 79.47 & 3.4 & $1 \pm 2$ \\
$1993 / 04 / 22$ & 111250. & 43.32 & 79.72 & 2.0 & $0.5 \pm 1$ \\
\hline
\end{tabular}

$\mathrm{D}=$ Distance to the seismogenic structure from the best earthquake location (with least travel time residual). \pm a: indicate the estimated maximum uncertainty for location determinations.

help constrain seismic source characteristics, an important input parameter for both probabilistic and deterministic hazard evaluation.

\section{EXISTING EARTHQUAKE FILES}

The first comprehensive seismicity compilation of eastern Canada was carried out by Smith $(1962,1966)$ who documented 20 earthquakes, which occurred during the 19th and the first half of 20th centuries, in the western Lake Ontario region. None caused effects that exceeded intensity VI on the Modified Mercalli scale $(\mathrm{MMI}=\mathrm{VI})$. A later compilation by Basham et al. (1979), with further refinements by Basham et al. (1982), led to interpreting different locations and values for severity of the ground shaking.

The earthquake data files currently used for seismic hazard assessment in eastern Canada have magnitude-date limits that accept only $M \geqslant 6$ events since $1900, M \geqslant 5$ events since $1940, M \geqslant 4$ events since 1960 and $M \geqslant 3$ events since 1970 (Basham et al., 1985; Adams and Basham, 1991; Drysdale, 1991). This compilation is based on a screening criterion which uses varying completeness periods for different magnitude ranges as defined by Weichert (1980). The selected listing has improved the accuracy and homogeneity of the data base for probabilistic hazard assessment. However, considerable data and information on earthquakes of the early 20th and previous centuries, which are useful for deterministic source zone definitions, have been disregarded. These include 20 historical events, in particular, the July 6 th, 1873 earthquake, an intensity $\mathrm{MMI}=\mathrm{VI}$ event, about $15 \mathrm{~km}$ west of Welland, and the May 2nd, 1877 earthquake, felt in the vicinity of Oshawa (Smith, 1962). The recent compilation by Martini and Bowlby (1991) shows a much more complete record of seismicity for the region (Fig. 1) with entries from Canadian and American seismological agencies.

The western Lake Ontario region is marked by earthquake clusters which occur in the Burlington-Hamilton, Welland and Niagara Falls areas, and near Attica, New York (Fig. 1). There has also been scattered activity, mostly in the central part of the region. An updated recurrence relation for this region is

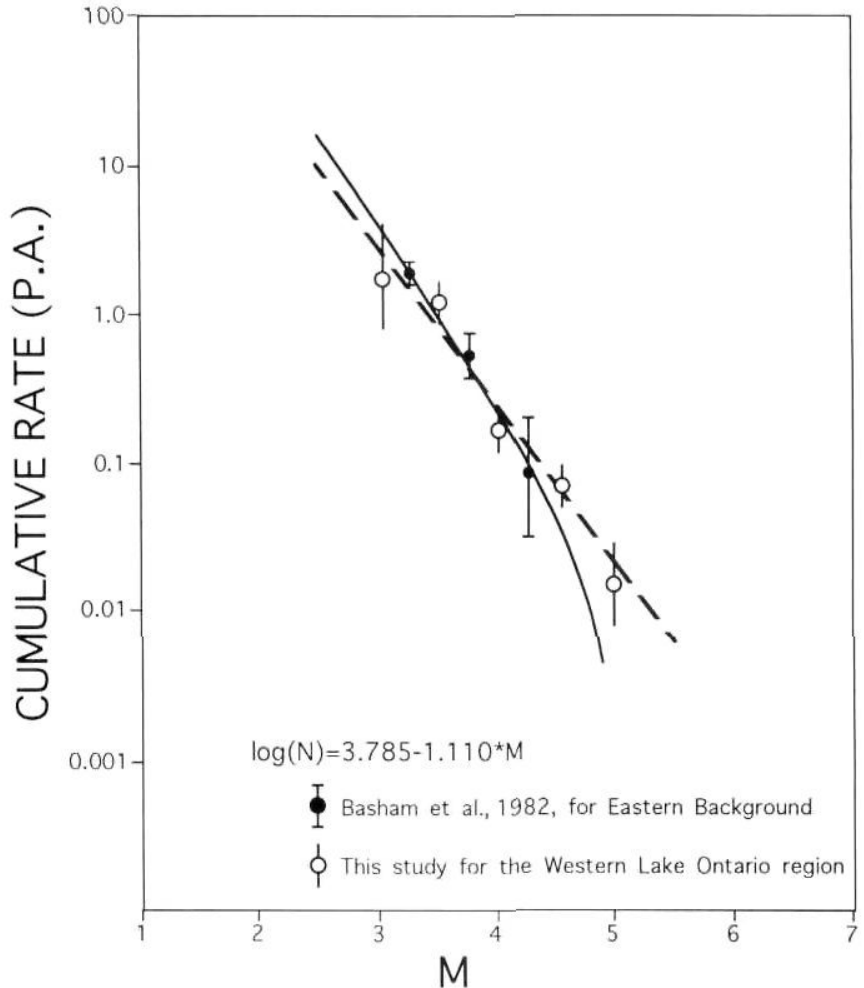

FIGURE 2. The magnitude-recurrence relationship for the western Lake Ontario region compared to that for the eastern background zone (Basham et al.,1982).

Les relations entre la magnitude et la récurrence dans la région de l'ouest du lac Ontario comparées aux données de Basham et al. (1982) pour l'est du Canada

given in Figure 2, which indicates that there is a higher probability of occurrence of a magnitude $5\left(>10^{-2} /\right.$ annum) earthquake than was expected before. It also shows that the upper bound magnitude may be greater than the $M=5$ suggested by Basham (1975). In addition to defining seismic source zones, this complete data set can be used in a deterministic approach for estimating the maximum expected magnitude $(\mathrm{Mx})$ in the region. This can reduce the existing uncertainty for those seismic risk assessments which are based solely on the probabilistic approach.

\section{SOURCE OF ERRORS AND ACCURACY OF THE SEISMICITY DATA}

Local earthquakes, particularly microtremors, could not be detected or reliably located before the full deployment of the Eastern Canadian Telemetered Network (ECTN). The first three stations of the ECTN (Ottawa, Montréal, and Maniwaki) were put into operation in 1974 and the network was gradually completed in 1978. The area of full coverage of the ECTN mostly lies along the Ottawa and St. Lawrence valleys, western Québec, and New Brunswick where several moderate to large magnitude earthquakes have occurred in recent times. The closest seismographic stations to the western Lake Ontario region consist of an analogue recorder at Effingham (EFO), near Niagara Falls, and a digital telemetered station at Welcome (WEO), about $90 \mathrm{~km}$ east of Toronto, which became operational in April 1982. 
There is a very limited area, in the western Lake Ontario region, covered by at least three stations, necessary to allow reliable computation of hypocentres of magnitude $M_{n} \leqslant 3$ earthquakes. The detection threshold for both WEO and EFO is $M_{n}=2.5$, at respective radii of 120 and $90 \mathrm{~km}$, with no third station coverage to yield a reliable location determination. Thus, the lack of a sufficient number of stations capable of detecting earthquakes is a major source of location error. Another important contributor to location error stems from different network biases. This is a function of the combination of stations used in various time periods to compute earthquake locations. This source of error was demonstrated by testing quarry blast mislocations in the region (Mohajer, 1987). For the data file prior to 1964, instrument time code marks are not as reliable as the recent ones and, therefore, this inherent source of error may not be improved. The phase readings of these earlier data files are inconsistent and less reliable than those in data files collected after 1964, and much less reliable than those collected after installation of the ECTN (1978) for most parts of eastern Canada (R.J. Wetmiller, pers. comm.).

A search in the National Archives of Canada yielded only a few original seismograms that could be examined for undetected errors in the arrival-time data. The main purpose for re-examining the records was to note the contribution of each source of undetected errors to mislocations in the routine processing of data. Possible misinterpretation of seismograms by different analysts, variations in time-base corrections and mis-recording of data are among sources of mislocations for the earthquakes that occurred prior to 1964. The results obtained showed that phase identification was sometimes uncertain due to human error and/or a low signal to noise ratio, masking phase arrivals at some of the stations. The range of variations in phase identification was negligible when compared with inconsistencies found in the time base corrections. Depth distribution is also a key element in determining source parameters and correlating seismic events with geological structures. A limited number of stations and insufficient azimuthal coverage of the hypocentres have resulted in inaccurate depth determinations for most of the events in southern Ontario.

\section{RECOMPUTATION OF THE EARTHQUAKE LOCATIONS}

An attempt has been made to improve the hypocentral locations for those events which have sufficient input data to yield a better computational solution. The preferred solution was normally determined by smaller travel time residuals. Several current methods and codes were utilized for this purpose including joint and single event location approaches.

Joint Epicentre/Hypocentre Determinations (JED/JHD) are used to determine station travel time corrections, locations, and origin times of more than one earthquake simultaneously (Douglas, 1967; Dewey, 1971; Dewey and Gordon, 1984; Mohajer, 1987). This method is insensitive to crustal velocity models and uses travel time residuals as station adjustments for refining the earthquakes location. JED/JHD has been very successful in reducing the error due to station biasing, and has been used extensively in the U.S. (Dewey and Algermission, 1974; Dewey, 1979) and in the western Québec seismic zone (Mohajer, 1991). Details of application of the method are given in Mohajer $(1987,1992)$.

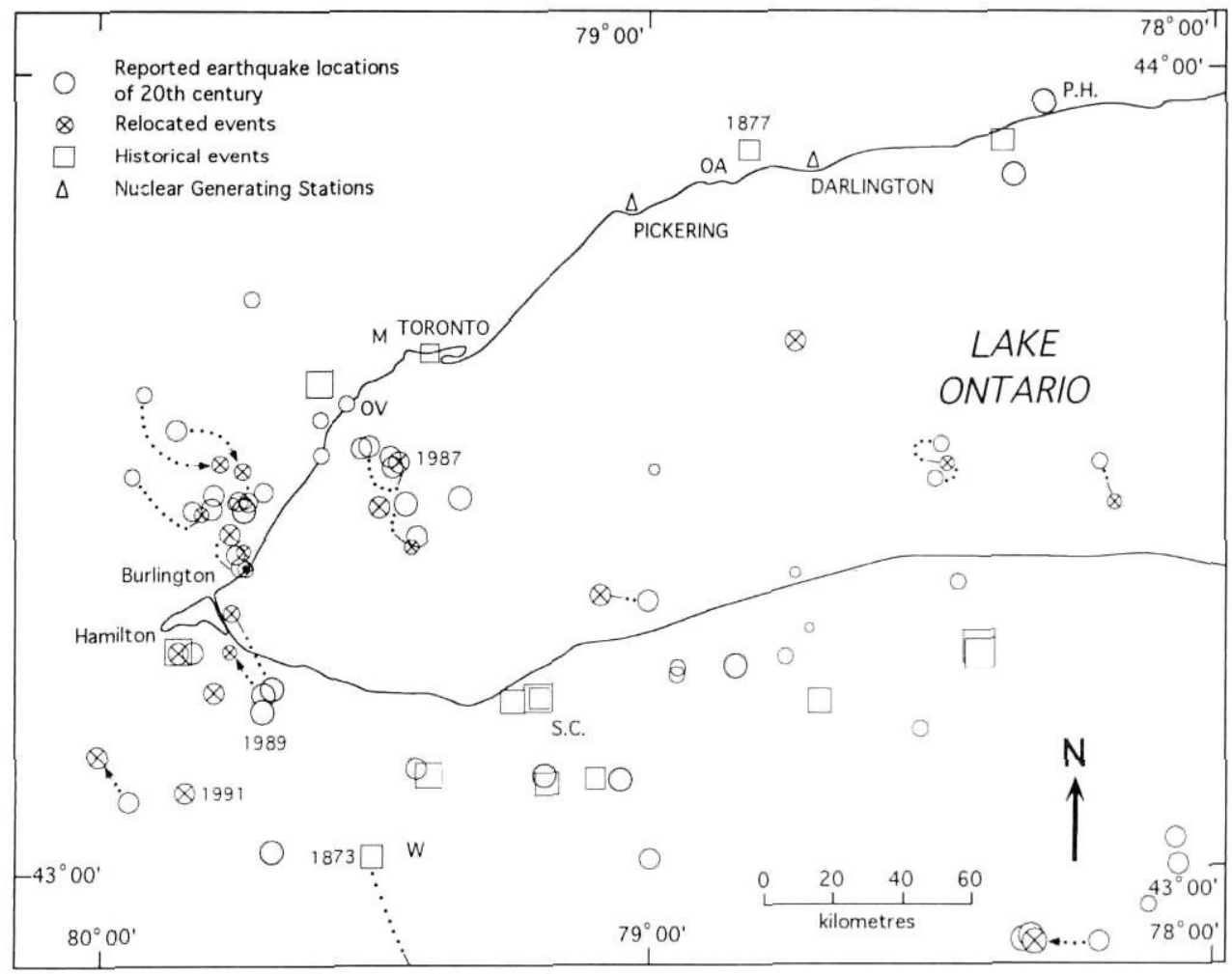

FIGURE 3. Epicenters in the western Lake Ontario region. Original and revised locations are connected by broken lines. $M=$ Mississauga, $\mathrm{OA}=$ Oshawa, OV = Oakville, $P . H .=$ Port Hope S.C. $=$ St. Catharines and $W=$ Welland. 1873, 1877, 1987, 1989 and 1991 are the years of occurrence.

Épicentres dans la région de l'ouest du lac Ontario. Les empla. cements originels et corrigés sont reliés par des pointillés. $O A=$ Oshawa, OV = Oakville, P.H. = Port Hope, S.C. $=$ St. Catharines et $W=$ Welland. Les séismes sont survenus en 1873, 1877, 1987, 1989 et 1991. 
Based on a thorough examination of the data it was concluded that, except for a few well recorded events, the existing seismicity data set for the western Lake Ontario region could not be substantially improved by the JHD/JED computation technique. However, there are a few events which yielded a better solution through the use of the "HYPOCENTRE" program (Linert et al., 1986; Mohajer, 1987) or LithoLoc (Asudeh et al., 1991). Several events were also selected from the list of locations, given in the Canadian Earthquakes National Summary bulletins (e.g. Drysdale et al., 1992), when they showed smaller travel time residuals. This resulted in a compilation of relocated events and selected earthquakes which had the least error margins (Figs. 3 and 6). The previous and recalculated epicentral locations are plotted in Figure 3 and re-plotted with a seismotectonic interpretation in Figure 6.

\section{HISTORICAL EARTHQUAKES AND FELT REPORTS}

The documented history of settlements in southern Ontario and the available reports on paleoseismicity do not extend back much beyond two centuries. This time span is shorter than the return periods for major earthquakes (e.g. 700 years) that have occurred in Iran and Turkey (e.g. Mohajer and Nowroozi, 1979; Ambraseys and Melville, 1982). Nevertheless, very interesting information on felt earthquakes in the region during the 19th century has been compiled by Smith (1962). Mohajer (1989) added to the information contained in the compilation of Smith (1962) by reporting on the previously undocumented 2 November 1870, and 23 May 1877, MMI=IV earthquakes in the Niagara region (Fig. 3). Although there is some debate on the accuracy of the inferred epicentral locations and size of the historical earthquakes, the existing information may help identify potentially active geological structures.

Significant felt events in recent times include a $M_{L}=3$ earthquake, in June 1975, the first event to be well documented in the Burlington-Oakville area (Wetmiller, 1980). A group of 16 small magnitude, but widely felt, earthquakes was reported in the same area between 1975 to 1983 . Wetmiller (1980) deployed a portable seismograph for a period of about 4 months from December 1979 to April 1980 and recorded 12 microearthquakes in the Burlington area. On October 4, 1983 a $M_{L}=3.1$ earthquake, with an estimated intensity $M M I=\mid V$, was strongly felt in the Burlington, Oakville and Hamilton area. An event of $M=2.2$ had occurred in the same general area on September 11, 1981. Near surface minor rock deformation was suggested as a possible cause of these earthquakes (Wetmiller, 1980). However, the documented depth distribution for all earthquakes in this region (Fig. 4) requires other explanations for the source of local seismicity. Although estimated depths for 23 events are shallower than $5 \mathrm{~km}, 34$ events have occurred at mid- to upper-crustal depths ranging from 5 to $20 \mathrm{~km}$.

The strongest event in recent years was a $M_{n}=3.4$ earthquake, which occurred beneath western Lake Ontario, on July 23, 1987, and was felt in Toronto, Burlington, parts of Hamilton, and St. Catharines. The severest shaking was felt in Mississauga and Oakville, where it was reported that many people were awakened, walls moved sideways, and windows, doors and dishes rattled. A felt intensity level of $\mathrm{MMI}=\mathrm{IV}+$ may be assigned to this earthquake. However, the maximum epicentral intensity is not known because the focus of the earthquake was in the crust underlying the lake. The preliminary co-ordinates for the July, 1987 event were given as $43.510^{\circ} \mathrm{N}, 79.530^{\circ} \mathrm{W}$ and $6.98 \mathrm{~km}$ depth, but the epicentre was later relocated to $43.491^{\circ} \mathrm{N}, 79.472^{\circ} \mathrm{W}$ (Drysdale et al., 1988). The available azimuthal coverage of the stations for this event was not complete, particularly from the east and west sides. Lack of an appropriate data base compatible with the JED method requirements (Mohajer, 1987) prohibits the use of the JED method for recomputation of this event and most of the similar microearthquakes. Nevertheless, a relocation of the 1987 event using the "HYPOCENTRE" program and a calibrated velocity model (Mohajer, 1987), together with the ' $A$ ' quality phase readings, yielded the geographical coordinates of $43.445^{\circ} \mathrm{N}, 79.451^{\circ} \mathrm{W}$ and $17.8 \mathrm{~km}$ depth

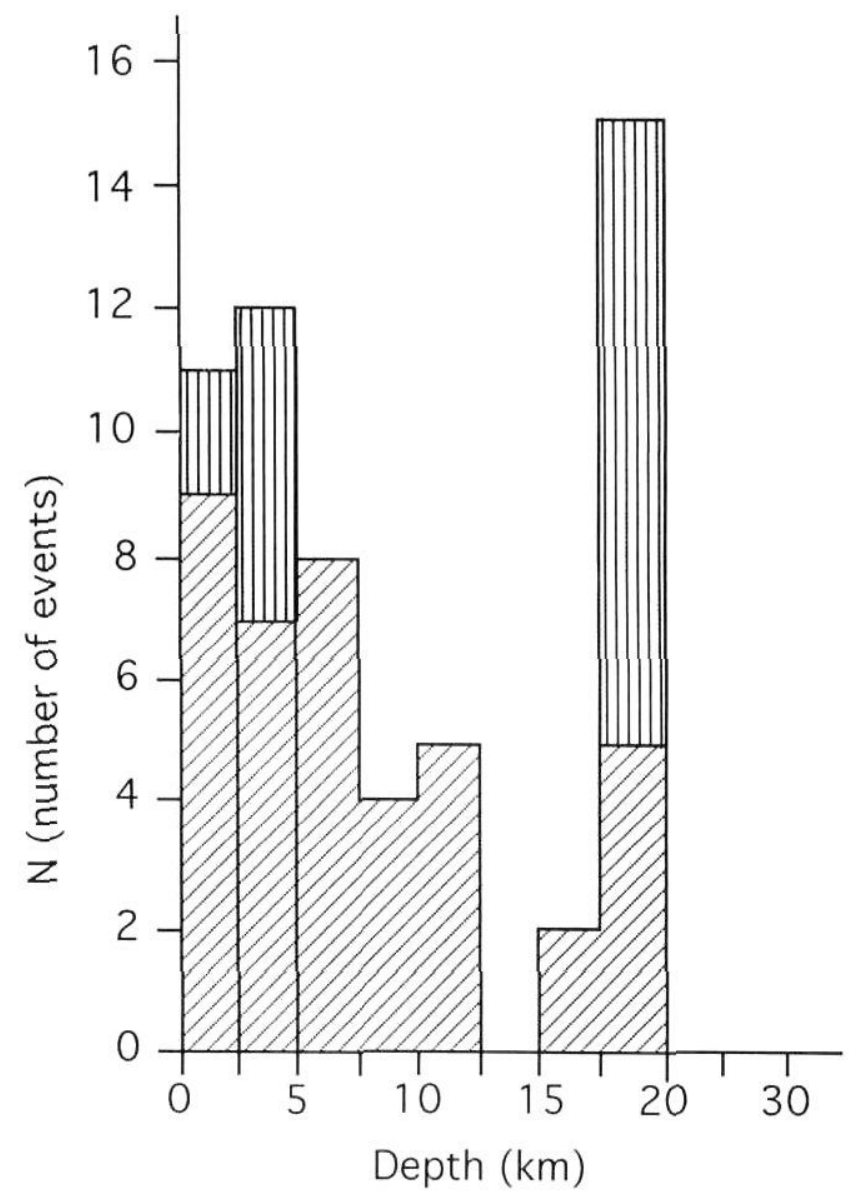

Depth distribution of the best available location computation in the western Lake Ontario region

Pegged events at 1, 5 and $18 \mathrm{~km}$ as determined by the Geological Survey of Canada

FIGURE 4. Depth distribution of earthquakes in the western Lake Ontario region.

Répartition des séismes selon leur profondeur dans la région de l'ouest du lac Ontario. 
(Fig. 3). This solution resulted in smaller time residuals when the observed and the calculated travel times were compared. The newly calculated location is under the lake, $23 \mathrm{~km}$ from downtown Toronto (Fig. 3). The possible errors of the relocated event is on the order of $2 \mathrm{~km}$ in the east-west direction, $1.4 \mathrm{~km}$ in the north-south direction, and $2.2 \mathrm{~km}$ in depth. A previous tremor shook Mississauga, less than 4 months earlier, on March 6, 1987 and a second was felt on March 8, 1987 in northwestern metropolitan Toronto. The radius of perception of the March 6 earthquake was much smaller than that of the July 23 earthquake.

Another small magnitude earthquake, measuring $M_{n}=3.3$, was felt throughout the Mississauga, Oakville, Burlington and Hamilton corridor, on August 5th, 1989. The vibrations occurred mostly on the northwest side of Lake Ontario between Burlington and Toronto, although the epicentre, reported by Lamontagne and Drysdale (1990), was located on the southern side of the lake, just east of Hamilton (Figs. 1 and 3). No property damage nor injuries were reported from the quake, which struck at 5:08 p.m. local time, though a few residents reported that their china was smashed during the tremor. This event was recorded by 36 stations in Canada and the USA at distances ranging from 8 to $900 \mathrm{~km}$. The location computation gives epicentral coordinates of $43.287^{\circ} \mathrm{N}$ and $79.761^{\circ} \mathrm{W}$, with an estimated depth of $5 \mathrm{~km}$. The traveltime residuals of the computed hypocentre have a root mean square (RMS) value of $0.3 \mathrm{sec}$. Attempts to recompute the location of this event did not improve the results because of the limited near source seismographic station coverage. Another small earthquake occurred on August 9th, 1989 but

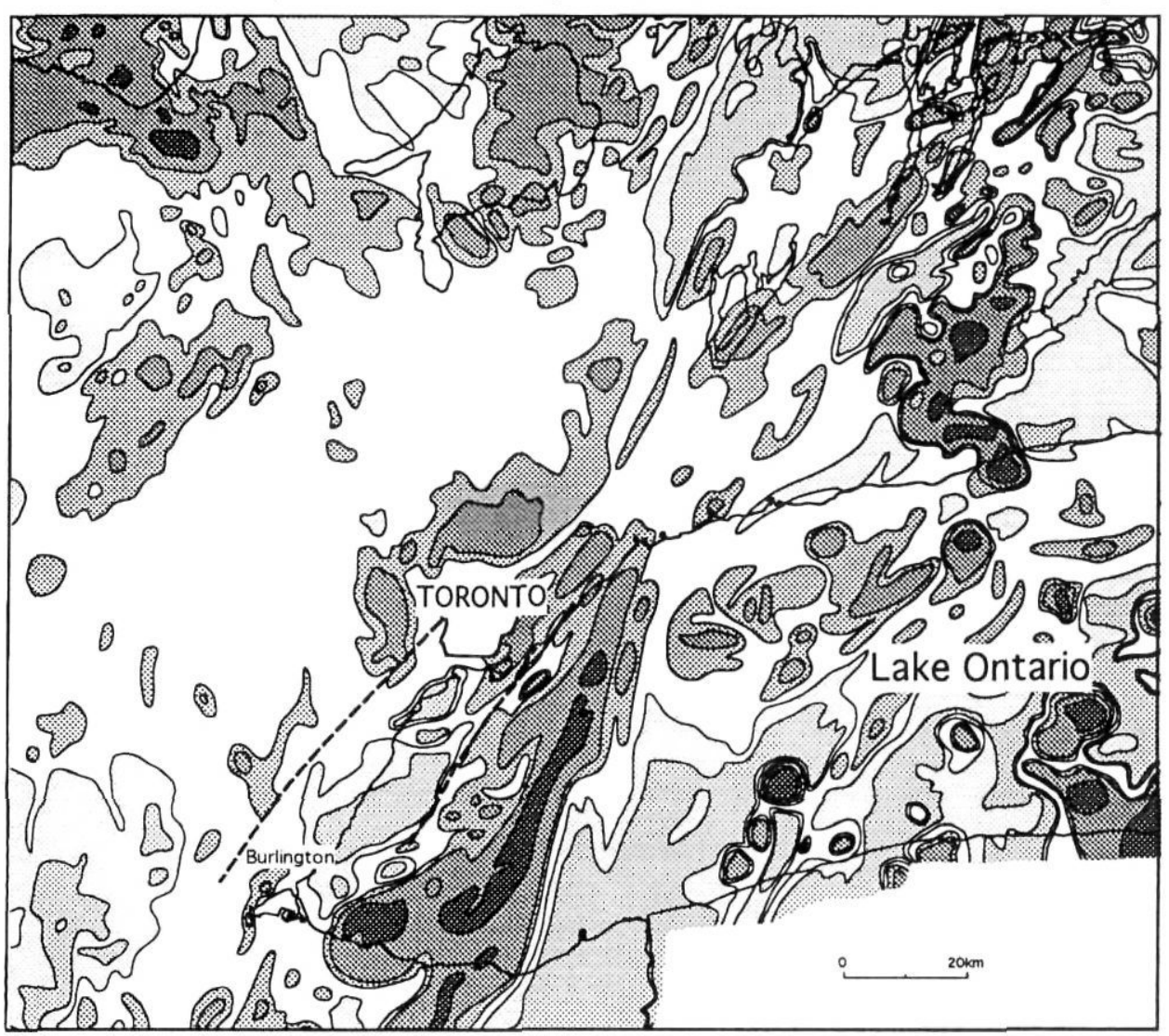

was recorded at only two stations. The estimated magnitude of this event, which was considered as the aftershock of the August 5th event, was $M_{n}=2.2$.

A well recorded event in the western Lake Ontario area was an $\mathrm{M}=3.2$ that occurred about $7 \mathrm{~km}$ south of Hamilton on December 14, 1991. This event was felt throughout the region, and is typical of the events that usually strike the area at least once every two years. Recomputation of the earthquake location here resulted in new coordinates which are only $200 \mathrm{~m}$ to the west.

It appears that most of earthquakes felt in the western Lake Ontario region after 1978 were recorded by the ECTN and the computed locations are the best that could be achieved with the existing seismic network configuration. Considerable data on microearthquakes below human perception, usually $\mathrm{M}<3$, may have been missed by the ECTN. Installation of the east of Toronto network (EOTN) and southern Ontario network (SON) has improved the detection threshold for microearthquakes since 1991 (Mohajer, 1991; Mereu, 1992). This has been demonstrated recently by three well-recorded, $M=2$ earthquakes that occurred under Lake Ontario on April 2, 22 and 26, 1993, 7 km south of Port Hope, just east of Burlington and $40 \mathrm{~km}$ southeast of Oshawa respectively.

\section{SEISMOTECTONIC RELATIONS AND SUGGESTED SOURCE ZONES}

Seismic activity in eastern Canada has generally occurred in areas where no simple association with surface geological

FIGURE 5. Total field aeromagnetic map of the western Lake Ontario region showing the lineaments bounding the TorontoHamilton Seismic Zone (THSZ, Fig. 6).

Carte aéromagnétique de la région de l'ouest du lac Ontario montrant les linéaments limitant la zone sismique de TorontoHamilton (voir la fig. 6). 
features has been established. However, there is growing recognition that deep, and poorly-understood, basement structures influence the location of seismic events and, subsequently, control the general seismicity pattern (e.g. Sanford et al., 1985; Wallach and Mohajer 1990; Mohajer et al., 1992). The seismicity and seismotectonics of eastern Canada have recently been updated and analyzed by Adams and Basham (1991) who considered southern Ontario as part of the southeastern background zone of seismicity, characterized by scattered earthquakes outside the active seismic zones of eastern Canada. Adams and Basham $(1989,1991)$ also postulated that the seismically active St. Lawrence rift extends upstream through lakes Ontario and Erie. Evidence supporting their hypothesis, which has important implications for earthquake hazard assessment in the western Lake Ontario region, has been accumulating as a result of the efforts of other researchers (e.g. Thomas et al., 1993; McFall and Allam, 1991; Martini and Bowlby, 1991; Wallach and Mohajer, 1990).

The present investigation suggests a spatial correlation between earthquake locations, and geological structures and linear geophysical anomalies (Fig. 6). The most prominent of these structures in the study area is the western boundary of the Central Metasedimentary Belt (CMB), known as the Central Metasedimentary Belt Boundary Zone (CMBBZ). The CMBBZ comprises a broad zone of highly deformed and tectonized gneissic rocks separating the Central Metasedimentary Belt on the east from the Central Gneiss Belt (CGB) on the west (Easton, 1992). In southern Ontario, the CMBBZ is covered by Paleozoic platform strata and overlying Quaternary glacial and interglacial deposits. Extension of this prominent geological boundary south of the exposed
Precambrian basement rocks and across Lake Ontario was delineated on the basis of conspicuous aeromagnetic, gravity and topographic lineaments by Wallach and Mohajer (1990), who named this extension the Niagara-Pickering linear zone (NPLZ). The CMBBZ/NPLZ coincides with valleys cut into Paleozoic strata both on the north and south sides of Lake Ontario suggesting reactivation of the basement structures and their upward propagation through the Paleozoic and Pleistocene cover (Eyles et al., 1993). South of Lake Ontario, the CMBBZ/NPLZ curves toward the SW and appears to connect with the Akron magnetic boundary (AMB) in Ohio (Wallach, 1990).

Earthquake epicenters define a northeast-oriented trend along the CMBBZ in the area extending from Bancroft, Ontario into western Québec, about 80 to $100 \mathrm{~km}$ west of Ottawa (Mohajer, 1992). The January 26, 1986, $m_{b}=4.9$ Leroy earthquake and aftershocks have been correlated with the AMB (Seeber and Armbruster, 1993). Epicentral alignments along the CMBBZ/NPLZ are also conspicuous on the Niagara Peninsula (Figs. 1 and 6). It, therefore, appears that the CMBBZ/NPLZ may be a seismically active structure. Consequently, it must be considered seriously in any future seismic source modelling for a realistic assessment of earthquake hazard in the western Lake Ontario region. Besides the CMBBZ/NPLZ, there are at least two other apparently seismogenic source zones, the THSZ and the HPF, which are described below.

\section{TORONTO-HAMILTON SEISMIC ZONE (THSZ)}

Proximal to, and extending beyond, the northwestern shoreline of Lake Ontario are two NE-oriented magnetic lineaments (Fig. 5), which are subparallel to the CMBBZ/NPLZ
FIGURE 6. Seismotectonic relations in the western Lake Ontario region. Seismicity data are based on the recomputed or the best available historical and instrumented locations. Additional information from Ontario Geological Survey (1991), Forsyth et al. (1987), Wallach and Mohajer (1990), Mohajer et al., (1992), and Thomas et al., (1993)

Corrélations sismotectoniques dans la région de l'ouest du lac Ontario. Les données sismiques sont fondées sur les sites les plus sûrs du point de vue historique ou déterminés par des instruments de précision et les sites corrigés. Les données complémentaires proviennent de la Commission géologique de l'Ontario (1991), Forsyth et al. (1987), Wallach et Mohajer (1990), Mohajer et al., (1992), et Thomas et al., (1993).

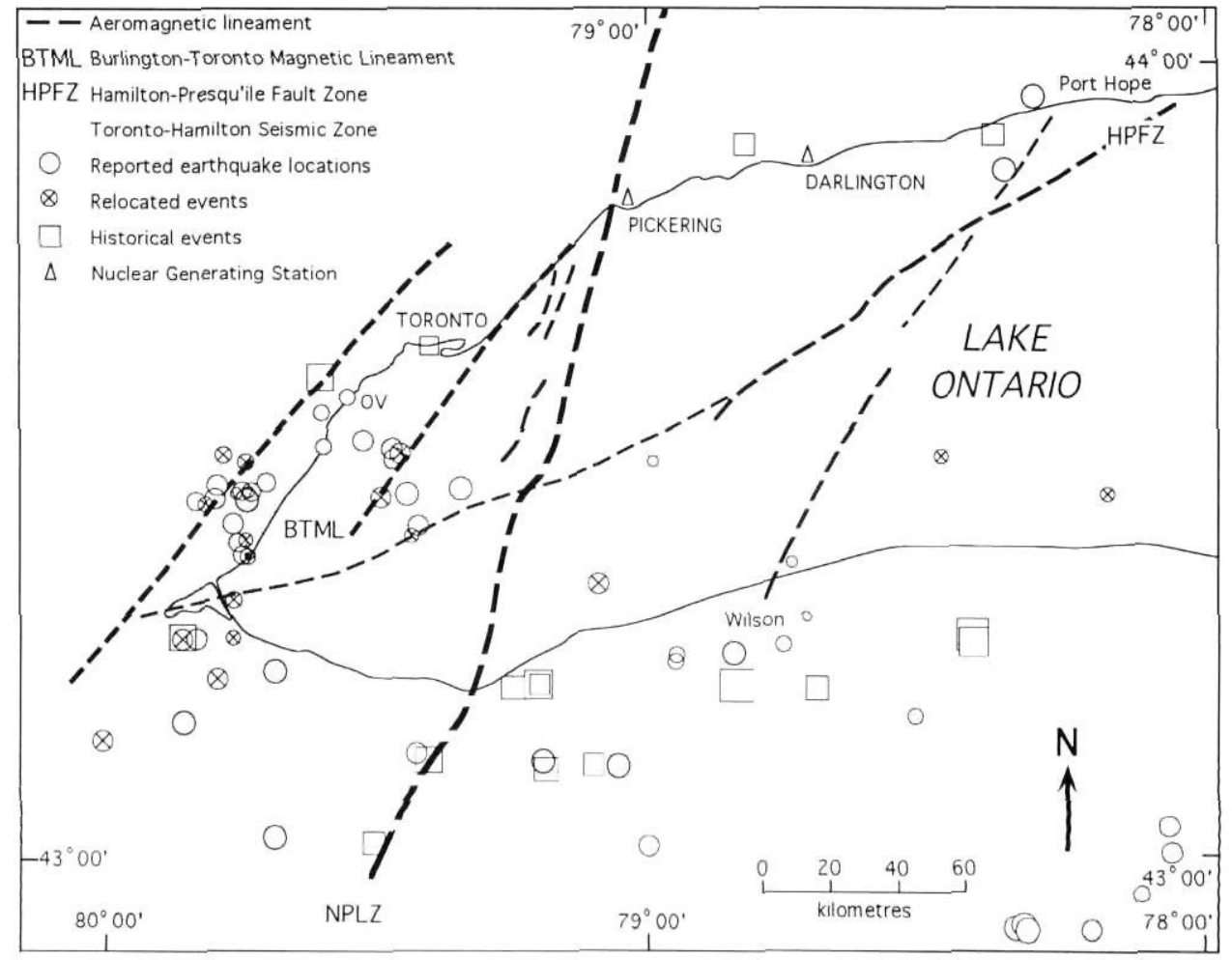

Géographie physique et Quaternaire, 47(3), 1993 
(Fig. 6). The more easterly of the two lineaments was described by Thomas et al. (1993), who named it the Burlington-Toronto magnetic lineament (BTML); the second lineament lies approximately $20 \mathrm{~km}$ to the west of the BTML. The area between these two linear magnetic anomalies shows the highest level of microearthquake activity in the western Lake Ontario region, and is herein named the Toronto-Hamilton seismic zone (THSZ) for the two largest cities contained therein. A cluster of eight of the best available earthquake locations, selected on the basis of the least rootmean-square (RMS) of travel time residuals (Mohajer, 1987), lies on, or near, the BTML (Fig. 6; Table I). The lineament to the west is spatially associated with at least thirteen earthquakes including two clusters, one of which is located east and north of Burlington, and the other just west of Oakville (Fig. 6, Table II).

\section{HAMILTON-PRESQU'ILE FAULT (HPF)}

A magnetic lineament that extends for over $200 \mathrm{~km}$, subparallel to the long axis of Lake Ontario, was first recognized by McFall and Allam (1991) who named it the HamiltonPresqu'ile lineament. This feature was later referred to, by Thurston et al. (1991), as the Hamilton-Presqu'ile fault (HPF). The HPF was delineated on the basis of geophysical data, geologic evidence which includes a $40 \mathrm{~m}$ offset of Paleozoic strata, and the physiography of the lake bottom (Thurston et al., 1991). Seven microearthquakes have occurred at, or very close to, the intersection of the BTML and the HPF and at least three more events have been reported along the east northeast extension of the HPF near Port Hope (Table III). Thomas et al. (1993) proposed that the HPF may lie along, or within, the extension of the St. Lawrence rift zone through Lake Ontario, as postulated repeatedly by Adams and Basham (e.g. 1989, 1991). If this is the case, then an earthquake of $\mathrm{M}=7$ must be considered in assessing seismic risk within the western Lake Ontario region, as suggested by

\section{TABLE ॥}

Earthquakes possibly associated with the western boundary of the Toronto-Hamilton Seismic Zone (THSZ)

\begin{tabular}{lllllr}
\hline Date & $\begin{array}{c}\text { Origin } \\
\text { Time }\end{array}$ & Lat. & Long. & Mag. & D (km) \\
\hline $1873 / 04 / 30$ & & 43.25 & 79.85 & 3.7 & $7 \pm 40$ \\
$1883 / 04 / 01$ & 06000 & 43.25 & 79.85 & 3.0 & $7 \pm 40$ \\
$1910 / 02 / 25$ & & 43.20 & 79.80 & 3.7 & $12 \pm 30$ \\
$1939 / 02 / 24$ & 00200 & 42.87 & 78.28 & 3.0 & $7 \pm 30$ \\
$1975 / 06 / 30$ & & 43.44 & 79.51 & 3.0 & $\leqslant 1 \pm 10$ \\
$1978 / 01 / 09$ & 13370 & 43.36 & 79.75 & & $\leqslant 2 \pm 5$ \\
$1978 / 01 / 21$ & 13180 & 43.36 & 79.75 & & $\leqslant 2 \pm 5$ \\
$1978 / 02 / 02$ & 14590 & 43.36 & 79.75 & & $\leqslant 2 \pm 5$ \\
$1978 / 03 / 05$ & 23210 & 43.48 & 79.75 & & $\leqslant 1 \pm 5$ \\
$1980 / 09 / 28$ & 034112 & 43.44 & 79.75 & 2.2 & $\leqslant 1 \pm 3$ \\
$1980 / 11 / 27$ & 173157 & 43.43 & 79.83 & 2.0 & $\leqslant 1 \pm 3$ \\
$1981 / 09 / 11$ & 162443 & 43.36 & 79.75 & 2.0 & $\leqslant 2 \pm 3$ \\
$1983 / 10 / 04$ & 171840 & 43.44 & 79.79 & 3.1 & $\leqslant 2 \pm 3$ \\
\hline
\end{tabular}

$D=$ Distance to the seismogenic structure from the best earthquake location (with least travel time residual). \pm a: indicate the estimated maximum uncertainty for location determinations.
Wallach and Mohajer (1990) and subsequently supported by Adams et al. (1993).

\section{CONCLUSIONS}

The stringent requirements of the JED/JHD earthquake location method do not allow for improved recomputations of all the hypocentres in the western Lake Ontario region. This is mainly due to limitations in the existing data files, resulting from insufficient instrument coverage. Nevertheless, some of the location computations have been refined by the JED and by the application of other computational techniques. More than half of the events, for which the hypocentral depths were computed, lie within the depth range of 5 to $20 \mathrm{~km}$ (Fig. 4), indicating that most of the microearthquakes in the western Lake Ontario region cannot be categorized as very shallow, as proposed by Adams and Basham (1991). There are enough well-located events to suggest that, when plotted on maps showing geological and geophysical lineaments, seismicity in southern Ontario is not randomly distributed, but is structurally controlled.

In summary, it is plausible to suggest a correlation between the prominent aeromagnetic and gravity lineaments, and small-magnitude events in the western Lake Ontario region. The features of particular interest are the CMBBZI NPLZ (Central Metasedimentary Belt Boundary Zone/ Niagara-Pickering Linear Zone), the THSZ (Toronto-Hamilton seismic zone) and the HPF (Hamilton-Presqu'ile fault). These features cannot be ignored when modelling seismic sources zones for future earthquake hazard assessments. For further refinements in the seismotectonic characteristics of the region it is necessary to continue to identify and document neotectonic features and to verify the level of activity of major faults through a local earthquake monitoring program. This measure would improve the data base for deterministic and

TABLE III

Earthquakes possibly associated with the Hamilton-Presqu'ile fault (HPF)

\begin{tabular}{llcccc}
\hline Date & $\begin{array}{c}\text { Origin } \\
\text { Time }\end{array}$ & Lat. & Long. & Mag. & $D(\mathrm{~km})$ \\
\hline $1873 / 04 / 30$ & & 43.25 & 79.85 & 3.7 & $\leqslant 1 \pm 30$ \\
$1883 / 04 / 01$ & & 43.25 & 79.85 & 3.0 & $\leqslant 1 \pm 30$ \\
$1886 / 02 / 13$ & & 43.95 & 78.30 & 2.4 & $5 \pm 30$ \\
$1910 / 02 / 25$ & & 43.20 & 79.80 & 3.7 & $7 \pm 20$ \\
$1929 / 08 / 12$ & 084500. & 44.00 & 78.30 & 3.0 & $\leqslant 5 \pm 20$ \\
$1939 / 01 / 14$ & 081016. & 43.25 & 79.85 & 3.3 & $\leqslant 1 \pm 15$ \\
$1980 / 01 / 21$ & 061609. & 43.25 & 79.76 & 2.5 & $0.5 \pm 3$ \\
$1987 / 03 / 20$ & 225000. & 43.45 & 79.00 & 1.4 & $3 \pm 20$ \\
$1989 / 08 / 05$ & 210757.6 & 43.21 & 79.68 & 3.2 & $\leqslant 2 \pm 2$ \\
$1991 / 12 / 14$ & 122359.2 & 43.155 & 79.87 & 2.5 & $\leqslant 7 \pm 1$ \\
$1993 / 04 / 02$ & 021955. & 43.827 & 78.36 & 1.0 & $9 \pm 5$ \\
$1993 / 04 / 26$ & 063524. & 43.562 & 78.566 & 2.5 & $11 \pm 10$ \\
\hline
\end{tabular}

$D=$ Distance to the seismogenic structure from the best earthquake location (with least travel time residual). \pm a: indicate the estimated maximum uncertainty for location determinations. 
probabilistic seismic hazard assessment for the critical facilities in this region.

\section{ACKNOWLEDGMENTS}

The writer is grateful to the Atomic Energy Control Board for funding this study. John Adams, Janet Drysdale and Robert Halliday of the Geological Survey of Canada provided information on the existing data files and archived seismograms of the earlier periods of this century. John Bowlby of Ontario Hydro and Gail McFall of the Ontario Geological Survey provided valuable discussions and reviews of the earlier version of the report to the AECB. Thanks are due to Ken Burke and Christine Powell, the official reviewers of the manuscript, and to Nick Eyles, for their comments and suggestions.

\section{REFERENCES}

Adams, J., 1982. Seismicity, earthquake focal mechanisms and crustal stresses in the Grenville Province, and their relation to the seismogenic rift structures of southern Canada. Geological Association of Canada/ Mineralogical Association of Canada, Abstract.

1987. Canadian crustal stress data-base: a compilation to 1987. Geological Survey of Canada, Open File Report 87-1622, 130 p.

Adams, J. and Basham, P.W., 1989. The seismicity and seismotectonics of Canada east of Cordillera. Geoscience Canada, 16: 3-16.

1991. The seismicity and seismotectonics of eastern Canada. p. 261-276. In D.B. Slemmons, E.R. Engdahl, M. Zoback, M. and D.D Blackwell, eds., Neotectonics of North America. Geological Society of America, Boulder, Geology of North America Decade Map Volume 1. $498 \mathrm{p}$.

Adams, J., Dredge, L.A., Fenton, M.M., Grant, D.R. and Shilts, W.W., 1993 Late Quaternary faulting in the Rouge River Valley, southern Ontario: seismotectonic or glaciotectonic? Geological Survey of Canada, Open File Report 2652, $60 \mathrm{p}$

Algermissen, S.W. et al., 1990. Probabilistic earthquake acceleration and velocity maps for the United State and Puerto Rico. U.S. Geological Survey, Miscellaneous Field Studies, Map MF2120, 1:7,500,000.

Ambraseys, N.N. and Melville, C.P., 1982. A history of Persian earthquakes Cambridge University Press, 219 p.

Armbruster, J.G. and Seeber, L., 1987. The 23 April 1984 Martic earthquake and the Lancaster seismic zone in eastern Pennsylvania. Bulletin of the Seismological Society of America, 77: 877-890.

Asudeh, I., Spencer, C. and Wetmiller, R., 1991. LithoSEIS Version 4.01 Geophysics Division, Geological Survey of Canada, Internal Report, 80 p.

Basham, P.W., 1975. Design basis ground motion for Darlington nuclear generating station A. Earth Physics Branch, Geological Survey of Canada Internal Report 75-16, 60 p.

Basham, P.W., Weichert, D.H. and Berry, M.J., 1979. Regional assessment of seismic risk in eastern Canada. Bulletin of the Seismological Society of America, 69: 1567-1602.

Basham, P.W., Weichert, D.H., Anglin, F.M. and Berry, M.J., 1982. New probabilistic strong ground motion maps of Canada. A compilation of the earthquake source zones, methods, and results. Earth Physics Branch, Geological Survey of Canada, Open File 82-33, 202 p.

1985. New probabilistic strong seismic ground motion maps of Canada. Bulletin of the Seismological Society of America, 75: 563-595.

Bowlby, J.R., Mohajer, A.A. and McMillan, R.K., 1988. Neotectonic observations in the western Lake Ontario region and potential impacts on seismic hazard estimates. Proceedings of the Geological Association of Canada Annual Meeting, Memorial University of Newfoundland, $24 \mathrm{p}$.
Bowlby, J., 1991. Recent surficial deformation provides geologic constraints for seismic source zoning in the Lake Ontario region. Proceedings, Geological Survey of Canada workshop on eastern seismicity source zones for the 1995 seismic hazard maps. Ottawa, 18-19 March 1991. Geological Survey of Canada, Open File Report No. 2437, Nov. 1991, 432 p.

Dewey, J.W., 1971. Seismicity studies with the method of Joint Hypocentre Determination. Ph.D Thesis. Department of Earth Sciences, University of California. Berkeley, 210 p.

- 1979. A consumer's guide to instrumental methods for determination of hypocentres. Engineering Geology, IV: 109-117.

Dewey, J.W. and Gordon, D.W., 1984. Seismicity of the eastern United States and adjacent Canada, 1925-1976. U.S. Geological Survey Professional Paper, $106 \mathrm{p}$.

Dewey, J.W. and Algermissen, S.W., 1974. Seismicity of the middle America arc-trench system near Managua, Nicaragua. Bulletin Seismological Society of America, 64: 1033-1048.

Douglas, A., 1967. Joint epicentre determination. Nature, 215: 47-48.

Drysdale, J., 1991. Eastern Canadian earthquake listing. Geological Survey of Canada data file, personal communication.

Drysdale, J. A., Horner, R.B., Spindler, C.L. and Lamontagne, M., 1988-1992. Canadian Earthquakes, National Summary. Geological Survey of Canada, Report File, GS2685-9.

Easton, R.M., 1986. Geochronology of the Grenville Province. In J.M. Moore, A. Davidson and A.J. Baer, ed., The Grenville Province. Geological Association of Canada, Special Paper 31: 127-173.

—_ 1992. The Grenville Province and the Proterozoic history of central and southern Ontario. Geology of Ontario, Ontario Geological Survey, Special Volume 4 (2): 714-904.

Eyles N., Boyce, J. and Mohajer, A.A., 1993. The bedrock surface in the western Lake Ontario region: Evidence of reactivated basement structure? Géographie physique et Quaternaire, 47(3):269-283.

Forsyth, D.A., 1981. Characteristics of the western Quebec seismic zone. Canadian Journal of Earth Sciences, 18: 103-119.

Forsyth, D.A., Thomas, M.D., Real, D., Abinett, D., Broome, J. and Halpenny, J., 1989. Geophysical investigations of the Central Metasedimentary Belt, Grenville province: Quebec to northern New York State. Proceedings of the 7th International Conference on Basement Tectonics. Queen's University, Kingston.

Kumarpelli, P.S. and Saull, V.A., 1966. The St. Lawrence valley system: A North American equivalent of the East Africa rift valley system. Canadian Journal of Earth Sciences, 3: 639-568.

Lamontagne, M. and Drysdale, J.A., 1990. Canadian earthquakes. Geological Survey of Canada, ECTN Bulletins.

Lienert, B.R., Berg, E. and Frazer, L.N., 1986. Hypocentre: An earthquake location method using centred, scaled, and damped least squares. Bulletin of the Seismological Society of America, 76: 771-783.

Martini, I. P. and Bowlby, J. R., 1991. Geology of the Lake Ontario basin: A review and outlook. Canadian Journal of Fisheries and Aquatic Sciences, 48: 1503-1516.

McFall, G.H. and Allam, A., 1989, Neotectonic investigations in southern Ontario; Prince Edward County-Phase I. Atomic Energy Control Board, Technical Report INFO-0343, 67 p.

- Neotectonic investigation in southern Ontario, Prince Edward County Phase 2. Atomic Energy Control Board, Technical Report INFO 0343-2, $97 \mathrm{p}$.

Mereu, R.F., Asmis, H. and Atkinson, G., 1992. The southern Ontario seismic network. 35th Conference International Association for Great Lakes Research, Abstract, University of Waterloo, 40 p.

Mohajer. A.A., 1987. Reappraisal of the seismotectonics of southern Ontario, task 1: relocation of earthquakes and seismicity patterns. Atomic Energy Control Board, Technical Report INFO-0293, MAGNEC Contribution 87-01, $73 p$.

_ 1989. Historical seismicity of southern Ontario: A 10-year period pilot study. Ontario Hydro, Internal Technical Report, $70 \mathrm{p}$ 
1991. Seismic source characterization in western Quebec and southern Ontario. Proceedings, Geological Survey of Canada workshop on eastern seismicity source zones for the 1995 seismic hazard maps. Ottawa, 18-19 March 1991, Open File Report 2437, 432 p.

Mohajer, A.A., 1992. Relocation of seismic events in western Quebec. Atomic Energy Control Board, Technical Report INFO-0393, 17 p.

Mohajer, A.A., Behzadi, H. and Berberian, M., 1975. Reflections on the rigidity of the Lut block and recent crustal deformation in eastern Iran. Tectonophysics, 25; 281-301.

Mohajer, A.A. and Nowroozi, 1979. The Tabas earthquake of September 16, 1978 in east central Iran. Geophysical Research Letters, 6: 689-692.

Mohajer, A.A., Eyles, N. and Rogojina, C., 1992. Neotectonic faulting near the Niagara/Pickering linear zone: Implications for earthquake hazard assessment in the Lake Ontario region. Geology, 20: 1003-1006.

Ontario Geological Survey, 1991. Bedrock geology map of Ontario.

Sanford, B.V., Thompson, J.G. and McFall, G.H., 1985. Plate tectonics - A possible controlling mechanism in the development of hydrocarbon traps in southwestern Ontario. Bulletin of Canadian Petroleum Geology, 33: 52-71.

Seeber, L. and Armbruster, J., 1993. Natural and induced seismicity in the Lake Erie-Lake Ontario region: reactivation of ancient faults with little neotectonic displacement. In J.L. Wallach and J.A. Heginbottom, eds., Neotectonics of the Great Lakes Area. Geographie physique et Quaternaire, 47(3): 363-378.

Smith, W.E.T., 1962. Earthquakes of Eastern Canada and adjacent areas 1534-1927. Dominion Observatory Publication, XXVI: 271-301.

1966. Earthquakes of eastern Canada and adjacent areas, 1928-1959. Dominion Observatory Publication, XXXII: 87-121.

Stevens, A., 1980. History of some Canadian and adjacent American seismograph stations. Bulletin of the Seismological Society of America, 70: 1381-1393.
Talwani, P., 1988. The intersection model for intraplate earthquakes. Seismological Research Letters, 59: 305-310.

Thomas, R.L., Wallach, J.L., McMillan, R.K., Bowlby, J.R., Frape, S., Keyes, D. and Mohajer, A.A., 1993. Recent deformation in the bottom sediments of western and southeastern Lake Ontario and its association with major structures and seismicity. In J.L. Wallach and J.A. Heginbottom, eds., Neotectonics of the Great Lakes Area. Géographie physique et Quaternaire, 47(3):

Thurston, P., 1991. Structural framework of Ontario. Proceedings, Geological Survey of Canada workshop on eastern seismicity source zones for the 1995 seismic hazard maps. Ottawa, 18-19 March 1991. Open File Report 2437, $432 \mathrm{p}$.

Viret, M., Bollinger, G.A., Snoke, J.A. and Dewey, J.W., 1984. Joint hypocentre relocation studies with sparse data sets. Bulletin of the Seismological Society of America, 74: 2297-2311

Wallach, J. L., 1990. Newly discovered geological features and their potential impacts on Darlington and Pickering. Atomic Energy Control Board, Technical Report INFO-0342, $20 \mathrm{p}$.

Wallach J. L. and Mohajer, A.A., 1990. Integrated geoscientific data relevant to assessing seismic hazard in the vicinity of the Darlington and Pickering nuclear power plants. Proceedings of the Canadian Geotechnical Conference, Québec City, October 10-12, 1990, p. 679-686.

Weichert, D.H., 1980. Estimation of the earthquake recurrence parameters for unequal observation periods for different magnitudes. Bulletin of the Seismological Society of America, 70: 1337-1346.

Wetmiller, R.J., 1980, Burlington Earthquake Series. Earth Physics Branch, Geological Survey of Canada, Internal Report.

Wetmiller, R.J., Horner, R.B., Stevens, A.E. and Rogers, G.C., 1983. Canadian earthquakes-1980. Earth Physics Branch, Geological Survey of Canada, no. $87,60 \mathrm{p}$. 